\title{
PEMBUATAN LUBANG RESAPAN BIOPORI DAN PUPUK KOMPOS CAIR DARI SAMPAH DI RW IX, KELURAHAN KALIREJO, KECAMATAN LAWANG, KABUPATEN MALANG
}

\author{
Sugeng Agung Wijaya ${ }^{1^{*}}$, Gatot Soebiyakto ${ }^{2}$, Mufidatul Ma'sumah ${ }^{3}$ \\ ${ }^{1}$ Mahasiswa Program Studi Teknik Sipil, Fakultas Teknik, Universitas Widyagama Malang \\ ${ }^{2}$ Program Studi D3 Mesin Otomotif, Fakultas Teknik, Universitas Widyagama Malang \\ ${ }^{3}$ Program Studi Ilmu Hukum, Fakultas Hukum, Universitas Widyagama Malang \\ *Email Korespondensi: sugengaw@gmail.com
}

\begin{abstract}
ABSTRAK
Secara umum masyarakat RW 09 Kelurahan Kalirejo telah mampu untuk mengembangkan potensi lingkungan sekitar, hal ini dibuktikan dengan adanya kelompok masyarakat yang berupaya mengembangkan pengelolaan limbah sampah non-organik yang sudah terstruktur dengan baik. Pemberdayaan serta pengolahan sampah baik sampah organik maupun anorganik merupakan salah satu masalah yang tidak asing lagi di tengah masyarakat. Dalam hal ini, berdasarkan hasil survei di kawasan RW 09, kelompok 3 menemukan bahwa pengolahan sampah terutama sampah organik di RW 09 ini dirasa kurang dimnfaatkan maksimal pengolahannya. Banyak dari sebagian masyarakat kurang peduli terhadap keadaan serta kelestarian di lingkungan sekitar berupa resapan air. Pembuatan Lubang Resapan Biopori (LRB) dan pupuk kompos cair dari sampah di RW 09 Kelurahan Kalirejo, Kecamatan Lawang, Kabupaten Malang dapat menambah jumlah resapan air dan mendapatkan manfaat sampah yang selama ini kurang digali. Sehingga nantinya, sumber air pada waktu kemarau tetap besar, dan tanaman sekitar rumah menjadi lebih subur karena mendapatkan pupuk kompos cair.
\end{abstract}

Kata Kunci: Lubang Resapan Biopori, Pupuk Kompos Cair, Sampah

\section{ABSTRACT}

Generally, the RW 09 Kalirejo urban village community has been able to develop the potential of the surrounding environment, evidenced by the existence of community groups who are trying to develop well-structured non-organic waste management. Empowerment and waste management, both organic and inorganic, is one of the familiar problems in the community. In this case, based on the results of a survey in the $R W 09$ area, group 3 found that the processing of waste, especially organic waste in $R W$ 09, was felt to be underutilised. Many of the people are less concerned about the condition and sustainability in the surrounding environment in the form of water catchment. Biopori Infiltration Hole (LRB) and liquid compost fertiliser from waste in RW 09 Kalirejo Sub-district, Lawang Sub-District, Malang Regency can increase the amount of water infiltration and get the benefits of waste that have not been dug up so far. So that later, the source of water during the dry season remains significant, and plants around the house become more fertile because they get liquid compost fertiliser.

Keywords: Biopori Infiltration Hole, Liquid Compost Fertilizer, Waste

\section{PENDAHULUAN}

Wilayah pedesaan dan masyarakat merupakan potensi dan basis dari pembangunan nasional secara keseluruhan, dimana keberhasilan pembangunan wilayah pedesaan merupakan tolak ukur dari keberhasilan pembangunan yang tercermin dari kemajuan negara. Mengingat serta sebagian besar penduduk Indonesia hidup di wilayah pedesaan, maka segala upaya dan pikiran perlu dikerahkan untuk lebih meningkatkan kesejahteraan masyarakat pedesaan. Hal ini menjadi tenggung jawab semua pihak baik lembaga pendidikan, instansi pemerintah/swasta maupun pemerintah itu sendiri. Perguruan Tinggi merupakan suatu lembaga pendidikan yang memiliki potensi dan berperan dalam memikirkan masalahmasalah pedesaan guna memotivasi, mengajak dan membuka wawasan berfikir masyarakat 
pedesaan agar dapat meningkatkan kemampuan serta memperluas wawasan berfikir. Sehubungan dengan permasalahan tersebut maka kehadiran mahasiswa KPM diwilayah pedesaan merupakan salah satu kegiatan nyata mahasiswa sebagai civitas Akademika Perguruan Tinggi dalam memberikan Pengabdiannya kepada masyarakat desa sesuai dengan Tri Dharma Perguruan Tinggi. Selain hal ini pelaksanaan Kuliah Pengabdian masyarakat merupakan penerapan Ilmu baik mahasiswa yang diterimanya selama dibangku kuliah. Oleh karena itu, setiap perguruan tinggi khususnya Universitas Widyagama Malang telah menyelesaikan kurikulum dengan kebutuhan pembangunan. Wujud dari pelaksanaan pembangunan dituangkan dengan mewajibkan setiap mahasiswa semester akhir untuk mengikuti Kuliah Pengabdian Masyarakat (KPM). Kuliah Pengabdian Masyarakat ini bertujuan untuk mengabdi, belajar dan menerapkan ilmu serta keahlian yang dimiliki untuk membina masyarakat dan melaksanakan bersama-sama dengan masyarakat pedesaan.

Berbekal dengan latar belakang problematika yang tengah dihadapi masyarakat saat ini yaitu dengan masalah kelingkungan dan perekonomian yang belum berkembang maka kelompok 3 KPM, Universitas Widyagama tahun 2019 angkatan ke-1 bermaksud untuk turut serta berkontribusi guna membangun kesejahteraan perekonomian dan kelestarian lingkungan masyarakat khususnya masyarakat RW 09 Kelurahan Kalirejo, Kecamatan Lawang, Kabupaten Malang. Secara umum masyarakat RW 09 Kelurahan Kalirejo telah mampu untuk mengembangkan potensi lingkungan sekitar, hal ini dibuktikan dengan adanya kelompok masyarakat yang berupaya mengembangkan pengelolaan limbah sampah nonorganik yang sudah terstruktur dengan baik.

Pemberdayaan serta pengolahan sampah baik sampah organik maupun anorganik merupakan salah satu masalah yang tidak asing lagi di tengah masyarakat. Dalam hal ini, berdasarkan hasil survei di kawasan RW 09, kelompok 3 menemukan bahwa pengolahan sampah terutama sampah organik di RW 09 ini dirasa kurang dimnfaatkan maksimal pengolahannya. Banyak dari sebagian masyarakat kurang peduli terhadap keadaan serta kelestarian di lingkungan sekitar berupa resapan air. Oleh sebab itu Kelompok 3 telah memilih program pembuatan Lubang Resapan Biopori (LRB) dan kompos cair. Kegunaan lubang biopori dibuat sebagai lubang resapan air (water saving) sehingga dapat mengurangi terjadinya genangan air yang berlebihan. LRB adalah sebuah lubang-lubang di dalam tanah yanng terbentuk akibat berbagai aktifitas organisme biota tanah seperti: cacing tanah, perakaran tanaman, rayap dan fauna tanah lainnya. Lubang-lubang yang terbentuk akan terisi udara, dan akan menjadi tempat berlalunya air di dalam tanah. Lubang ini adalah sebagai metode alternatif untuk meresapkan air hujan dan mengolah sampah organik, sampah yang dimasukkan kedalam lubang akan memancing fauna-fauna di dalam tanah untuk membuat terowongan kecil sehingga air cepat meresap. Melalui program pembuatan LRB ini, kita berharap permasalahan pengolahan akan sampah organik dan menambah resapan air dapat sedikit terlaksanakan (Kusmawati, et al., 2012; Sutandi \& Husada, 2013; Yohana, et al., 2017).

Pupuk kompos sering didefinisikan sebagai suatu proses penguraian yang terjadi secara biologis dari senyawa-senyawa organik yang terjadi karena adanya kegiatan mikroorganisme yang bekerja pada suhu tertentu di dalam atau wadah tempat pengomposan berlangsung. Bahan pembuatan pupuk organik yang lebih dikenal dengan kompos, dapat memanfatkan sayuran sisa rumah tangga, daun-daunan, rumput, buah-buahan yg busuk, nasi, dan bahan lain yg bersifat organik. Bahan-bahan tersebut mudah didapat dan setiap hari di sekitar rumah warga (Febrianna, et al., 2018; Kasmawan, et al., 2018.; Nur, et al., 2016). Hal itulah yang mendasari kami membuat alternatif pemecahan masalah terhadap hal tersebut untuk membantu lingkungan sekitar yaitu dengan memanfaatkan limbah tersebut dengan menjadikannya sebagai kompos yang menggunakan teknologi yang sederhana dan cara pembuatannya lebih mudah dibuat karena memanfaatkan dari bahan yang mudah didapat. Disamping itu pupuk organik memiliki manfaat serta mutu dan nilai yang ekonomis, pembuatannya lebih mudah karena memanfaatkan dari bahan yang mudah didapat. Melalui program pembuatan kompos cair ini, diharapkan masyarakat di RW 09 bisa mengolah limbah 
rumah tangga yg bersifat organik menjadi sesuatu yang berguna dengan cara yang lebih mudah dibuat dan bahan yang mudah didapat. Dan juga dapat membuka kesempatan baru bagi masyarakat untuk berwirausaha dengan hasil pupuk kompos cair.

\section{METODE}

Awal mula pelaksanaan tidak lepas dari koordinasi dengan ketua RW 09 untuk menjadi penghubung komunikasi antara humas kelompok 3 dan ketua dari para pemuda karang taruna RW 09. Selanjutnya penentuan jadwal pertemuan untuk melaksanakan sosialisasi dan pemberdayaan antara tim dari bidang Administrasi dan Pemerintahan di bantu tim dari program kerja biopori bidang Kelestarian Lingkungan dengan para pemuda karang taruna RW 09. Sosialisasi dan pemberian wawasan telah disampaikan, selanjutnya praktik pembuatan biopori dilaksanakan hari itu juga dan memberi kesempatan kepada ketua pemuda karang taruna RW 09 mengambil alih langsung pembuatan biopori di bawah pengawasan tim dari program kerja biopori bidang Kelestarian Lingkungan kelompok 3 .

\section{Lubang Resapan Biopori (LRB)}

Adapun langkah-langkah yang perlu dilakukan untuk pembuatan biopori adalah mempersiapkan peralatan yang diperlukan. Alat-alat yag dibutuhkan antara lain alat bor tanah, pipa PVC ukuran 4" yang dipotong dengan ukuran sekitar $30 \mathrm{~cm}$. Setiap potongan pipa diberi lubang tiap bagian sisinya, dan tutup pipa diberi lubang pada bagian atasnya. Setelah peralatan sudah siap, langkah berikutnya adalah:

1. Penentuan lokasi yang akan dijadikan sebagai tempat pembuatan lubang biopori.

2. Setelah menetukan lokasinya dilakukan pengeboran, siramlah tanah dengan air agar proses pengeboran menjadi lebih mudah.

3. Buatlah lubang dengan ukuran 1 meter $/ 100 \mathrm{~cm}$ dengan diameter lubang $10 \mathrm{~cm}$.

4. Setelah proses pembuatan lubang selesai, masukkan pipa PVC.

5. Kemudian, setelah pipa pvc terpasang, masukkan sampah - sampah organik yang berasal dari tanaman.

6. Terakhir, tutup pipa pve dengan penutup pipa yang sudah dilubangi bagian atasnya.

\section{Pupuk Kompos Cair}

Bahan dan alat yang dibutuhkan pembuatan pupuk kompos cair antara lain adalah limbah organik rumah tangga, sampah-sampah organik, toples untuk pengomposan dan hasil pengomposan, sendok makan, botol, gula, cairan EM4 dan air. Cara pembuatan alat komposter sebagai wadah pupuk kompos cair adalah sebagai berikut:

1. Buat satu lubang di bagian bawah ember/toples, posisi lubang harus lebih rendah sekitar $10 \mathrm{~cm}$ dari alas ember/toples. Lubang ini dipakai untuk pemasangan kran.

2. Lubangi ember/toples sesuai dengan pipa kran jangan sampai lubang terlalu besar agar tidak terjadi kebocoran.

3. Pasang kran pada lubang yang telah dibuat kemudian lem dengan lem paralon.

4. Kemudian Pasang Saringan di bagian bawah ember/toples dengan posisi harus di atas kran agar kran tidak tersumbat ampas pupuk kompos.

5. Untuk lebih efektif pakai 2 ember/toples kemudian pasang saringan di antara kedua ember / toples.

6. Alat Komposter siap di gunakan.

Sedangkan proses pembuatan larutan pengurai pupuk kompos cair dapat diuraikan seperti pada Gambar 1 dan Gambar 2 sebagai berikut:

1. Masukan gula dan EM4 sebanyak 1 sendok makan kedalam botol air mineral 600 $\mathrm{ml}$.

2. Isi botol air meineral $600 \mathrm{ml}$ yang sudah berisi gula dan EM4 tersebut dengan air bersih sampai air penuh lalu kocok botol air mineral $600 \mathrm{ml}$ tersebut sampai ketiga bahan tersebut tercampur sempurna. 
3. Setelah campuran gula, EM4 dan air bersih tercampur sempurna diamkan campuran tersebut ditempat teduh minimal 1 hari.

4. Setelah didiamkan selamat 1 hari, masukan sampah organik yang sudah dipotong kecil ke dalam wadah pengomposan dan bahan campuran tersebut.

5. Untuk pengomposan minimal selama 1 minggu dan juga setiap 1 hari sekali aduk wadah pengomposan agar sirkulasi udara bisa lancar.

6. Jika proses pengomposan selesai maka hasilnya bisa dimasukan ke dalam wadah penampungan dan siap digunakan.

7. Pengomposan tergantung pada karakteristik bahan yang dikomposkan, metode pengomposan yang diperlukan dan dengan atau tanpa penambahan aktivator pengomposan.

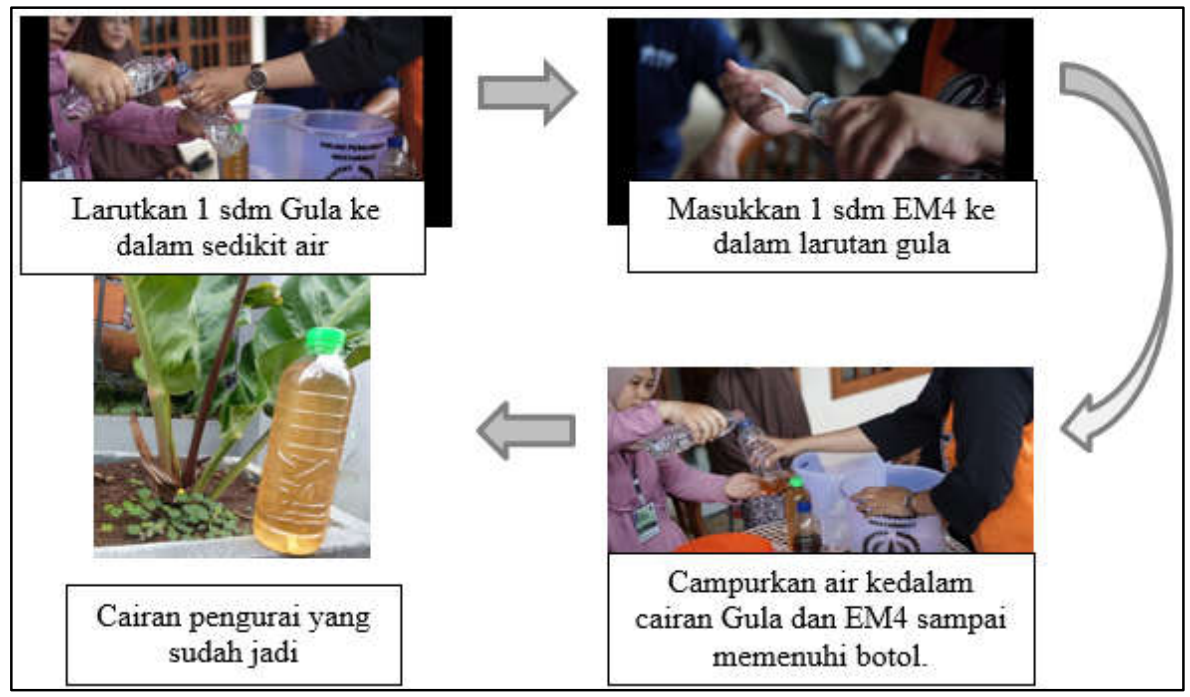

Gambar 1. Proses Pembuatan Larutan Pengurai

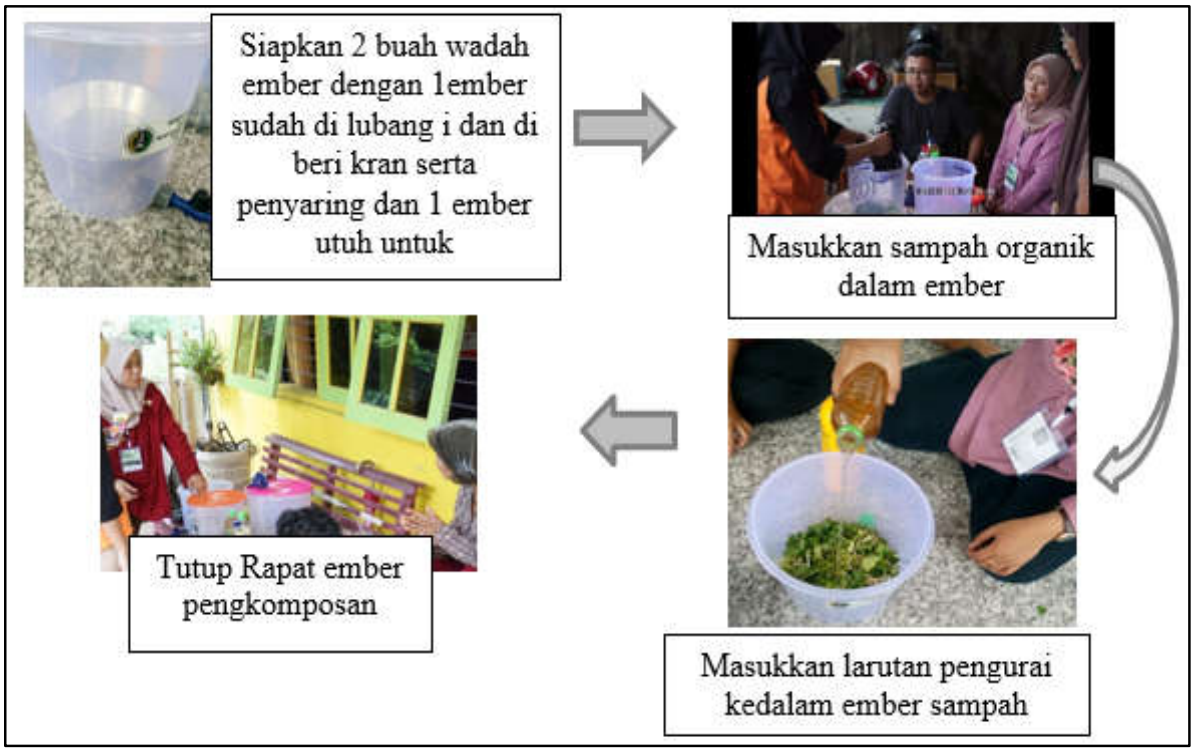

Gambar 2. Proses Pengkomposan Sampah Organik Rumah Tangga 


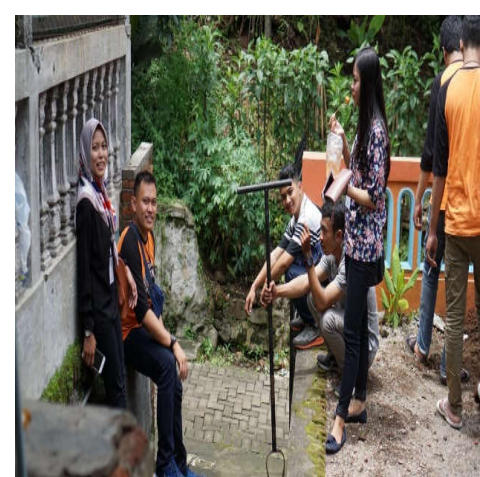

a

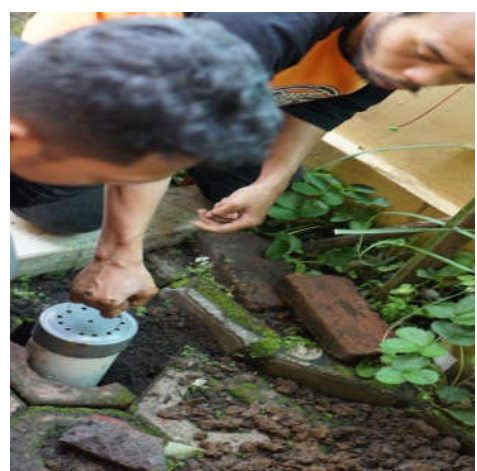

b

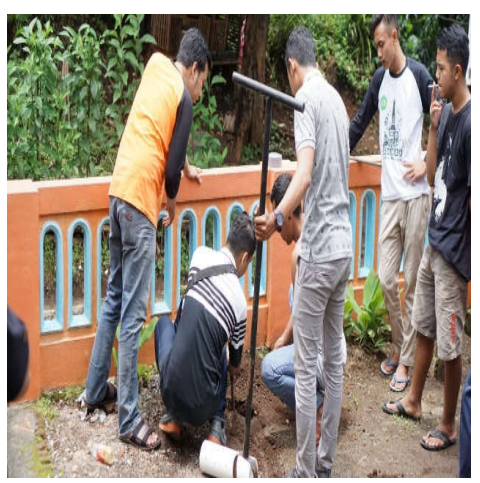

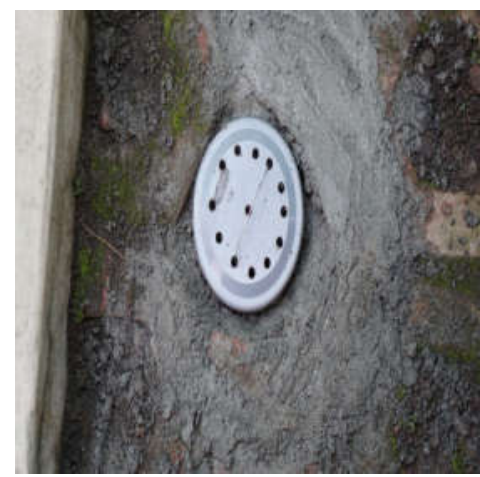

d

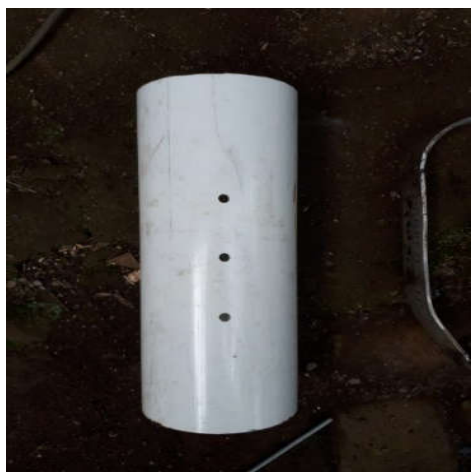

e

Gambar 3. Pembuatan Lubang Resapan Biopori (LRB)

\section{HASIL DAN PEMBAHASAN}

Setelah melalui proses pengerjaan selama 3 minggu, pembuatan lubang resapan biopori (LRB) di lingkungan RW 09 dapat dilihat hasilnya seperti pada Gambar 3. Hambatan yang kita temukan pada saat pembuatan LRB ini yaitu penentuan titik lubang biopori, kondisi tanah yang kering dan masih banyaknya batu sehingga menyulitkan saat melakukan pengeboran tanah serta proses pengecoran di daerah bibir lubang biopori terhadap tutup biopori. Program pembuatan Lubang Resapan Biopori (LRB) terlaksana 100\% sesuai dengan rencana program kerja, yang menghasilkan 7 biopori dengan ukuran lubang $10 \mathrm{~cm}$ dengan kedalaman lubang $80 \mathrm{~cm}$ yang sudah terbuat di masing - masing 1 lubang biopori ditiap RT di RW 09. 
Setelah lubang biopori jadi, masukkan daun-daun kering, sampah basah ke dalam lubang sampai penuh, hal ini dimaksud agar sampah terurai oleh cacing dan menjadi kompos serta mencegah material - material lain seperti pasir dan kerikil atau sampah non organik masuk ke dalam lubang biopori. Kemudian tutup lubang dengan tutup paralon yang telah di lubangi ( tutup paralon bisa di ganti dengan roster / angin - angin ). Setelah semua selesai, kita tinggal melakukan pemeliharaan seperti mengecek lubang apakah tersumbat sampah atau tidak dan menambahkan sampah organik apabila isinya telah berkurang dan menyusut akibat proses pelapukan. Kompos Biopori dapat di panen setelah $2-3$ minggu. Setelah di panen kita dapat mengisi lubang biopori dengan daun - daun kering dan sampah basah lagi hingga penuh. Hasil dari Biopori ini dapat di gunakan untuk pemupukan tanaman yang ada di rumah kita dengan pengambilan pupuk kompos yang sudah di diamkan minimal selama 2 - 3 minggu. Setelah beberapa minggu sampah organik yang ada di dalam LRB akan menjadi Pupuk Kompos Organik seperti pada Gambar 4.

\section{Cara Perawatan Biopori}

Lubang resapan biopori juga harus di rawat agar tetap terjaga kualitasnya dan dapat berfungsi dengan baik. Beberapa hal untuk merawat lubang biopori

1. Kita dapat mengisi lubang biopori dengan sampah organik secara bertahap setiap lima hari sekali sampai lubang terisi penuh dennga sampah.

2. Lubang resapan biopori yang sudah terisi penuh dengan sampah dapat kita biarkan selama tiga bulan agar sampah tersebut nantinya menjadi kompos.

3. Setelah tiga bulan, angkat kompos yang sudah jadi dari lubang biopori, dan lubang siap diisi kembali dengan sampah yang baru. Kompos pun siap digunakan untuk memupuk tanaman yang ada di halaman rumah.

Setelah melalui proses pengerjaan selama 3 minggu semua RT di RW 09, maka hasil pembuatan lubang resapan biopori (LRB) seperti pada Gambar 4. Hambatan yang kita dapatkan dalam pembuatan pupuk kompos cair yaitu:

1. Bau yang tidak sedap pada saat proses fermentasi (tergantung jenis sampah organik yang digunakan).

2. Pengumpulan sampah organik yang terlalu lama bisa berakibat pembusukan pada sampah organik tersebut sebelum proses fermentasi.

3. Waktu fermentasi sampah organik memakan waktu minimal 1 minggu.

4. Fermentasi cairan untuk sampah organik minimal 1 hari.

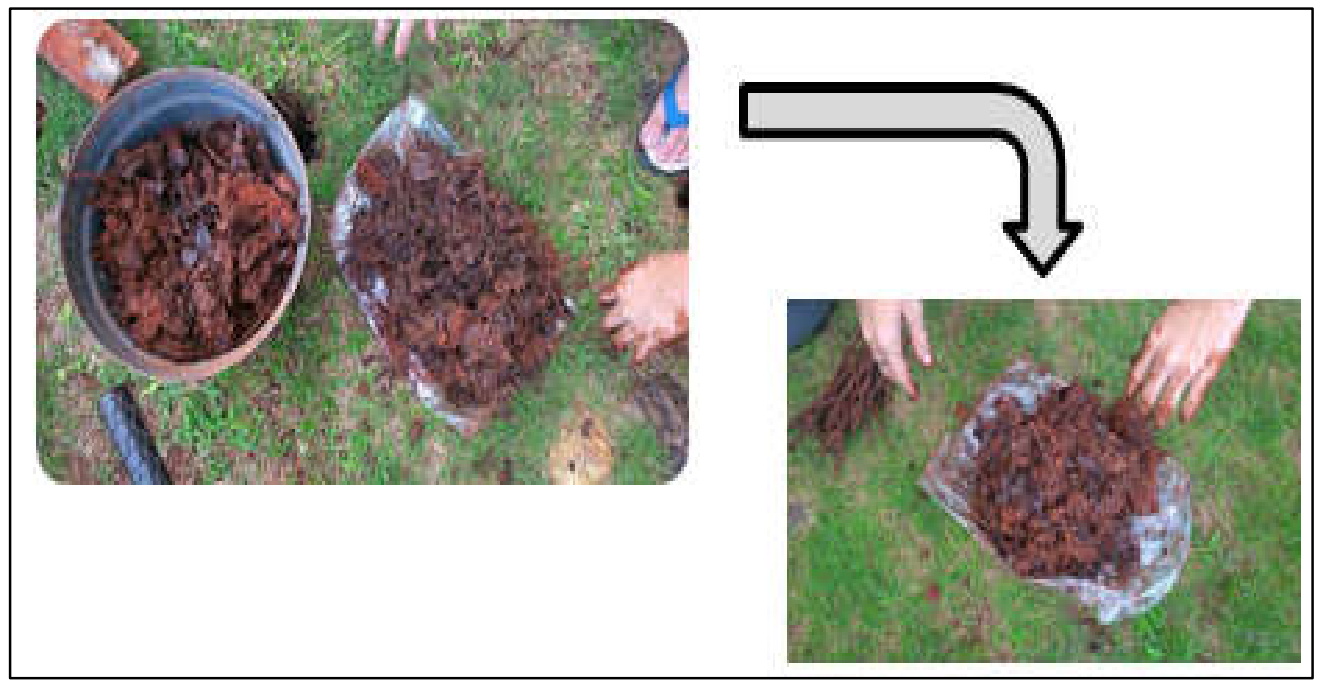

Gambar 4. Proses Pengkomposan Sampah Organik Rumah Tangga 


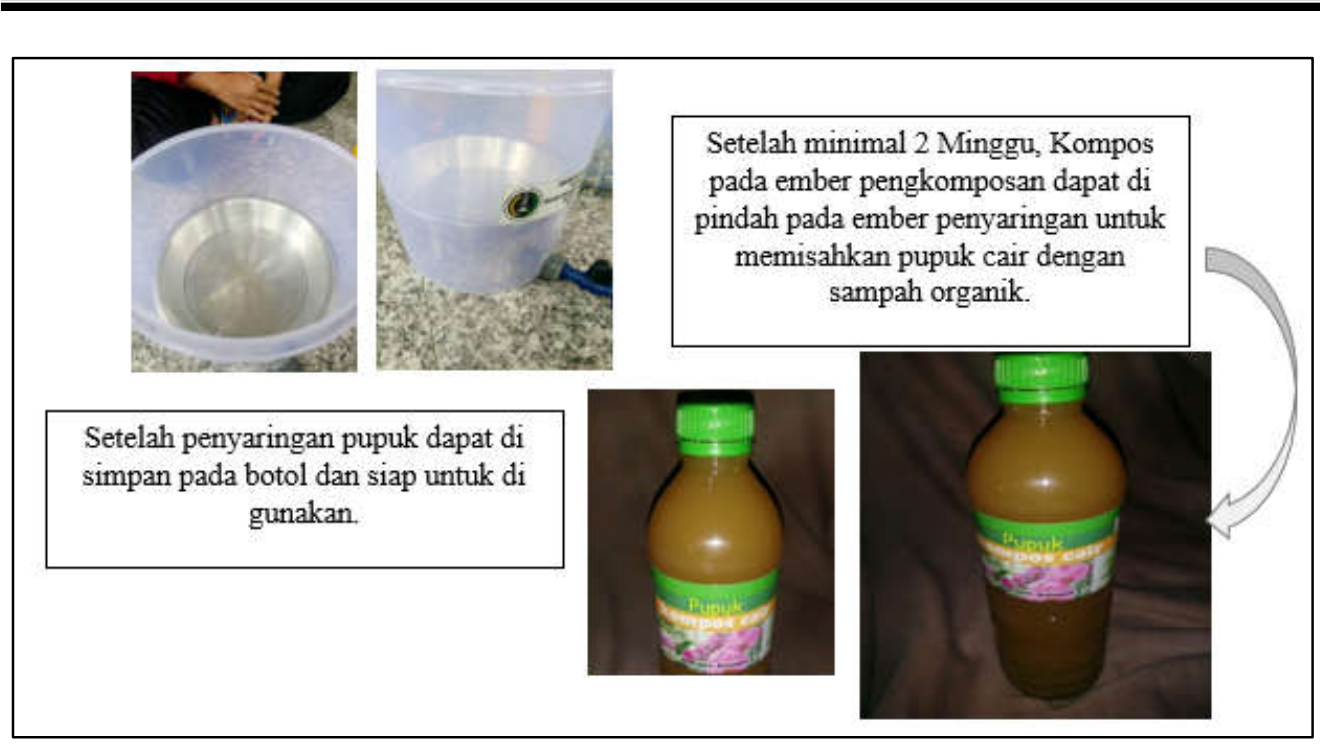

Volume 2 Nomor 2, oktober Tahun 2019

Gambar 5. Panen Pupuk Kompos Cair

\section{DAMPAK DAN MANFAAT}

Banyak sekali manfaat yang dapatdiperoleh dari biopori dan kompos cair, bila kita mau menerapkannya di lingkungan sekitar. Namun, hasil penerapannya akan lebih memuaskan jika kita semua mau bergotong-royong untuk menerapkannya secara bersamasama di lingkungan. Semakin banyak yang menerapkan, maka semakin besar manfaat yang diperoleh. Sampah organik yang dibuang di lubang biopori merupakan makanan untuk organisme yang ada dalam tanah. Organisme tersebut dapat membuat sampah menjadi kompos yang merupakan pupuk bagi tanaman di sekitarnya. Sehingga genangan air dapat dikurangi, dan diperoleh nilai tambah pada sampah organik yang selama ini hanya dibuang begitu saja.

\section{KESIMPULAN}

Program Kuliah Pengabdian Masyarakat (KPM) dapat meningkatkan ilmu dan pengetahuan masyarakat serta dapat menggugah masyarakat dalam berbagai bidang. Mahasiswa mendapatkan pengalaman dan ilmu kemasyarakatan yang tidak didapatkan di bangku kuliah dan masyarakat dapat menyerap ilmu yang dimiliki mahasiswa dalam meningkatkan wawasan mereka untuk kemudian diterapkan dalam kehidupan sehari-hari.

Pembuatan Lubang Resapan Biopori (LRB) dan pupuk kompos cair dari sampah di RW 09 Kelurahan Kalirejo, Kecamatan Lawang, Kabupaten Malang dapat menambah jumlah resapan air dan mendapatkan manfaat sampah yang selama ini kurang digali. Sehingga nantinya, sumber air pada waktu kemarau tetap besar, dan tanaman sekitar rumah menjadi lebih subur karena mendapatkan pupuk kompos cair.

\section{DAFTAR PUSTAKA}

Febrianna, M., Prijono, S. dan Kusumarini, N. (2018) 'Pemanfaatan Pupuk Organik Cair Untuk Meningkatkan Serapan Nitrogen Serta Pertumbuhan dan Produksi Sawi (Brassica juncea L.) Pada Tanah Berpasir', Jurnal Tanah dan Sumberdaya Lahan, 5(2), 1009-1018. 
Kasmawan, I. G. A., Sutapa, G. N. dan Yuliara, I. M. (2018) 'Pembuatan Pupuk Organik Cair Menggunakan Teknologi Komposting Sederhana 6. Buletin Udayana Mengabdi, 17(2), 114-120.

Kusmawati, T., Kusmiyarti, T.B., Gunasih, M.T., Bhayunagiri, I.B.P., Susila, K.D. dan Sutari, N.W.S. (2012) 'Penerapan Inovasi Teknologi Lubang Resapan Biopori Untuk Menjaga Ekosistem Tanah Daerah Rawan Banjir di Banjar Wirasatya, Denpasar Selatan', Buletin Udayana Mengabdi, 11(1), 24-30.

Nur, T., Noor, A.R. dan Elma, M. (2016) 'Pembuatan Pupuk Organik Cair Dari Sampah Organik Rumah Tangga Dengan Penambahan Bioaktivator EM4 (Effective Microorganisms)', Konversi, 5(2), 44-51.

Sutandi, M.C. dan Husada, G. (2013) 'Penggunaan Lubang Resapan Biopori Untuk Minimalisasi Dampak Bahaya Banjir Pada Kecamatan Sukajadi Kelurahan Sukawarna RW004 Bandung', Konferensi Nasional Teknik Sipil (Konteks 7), 24-26 Oktober 2013, Solo.

Yohana, C., Griandini, D. dan Muzambeq, S. (2017) 'Penerapan Pembuatan Teknik Lubang Biopori Resapan Sebagai Upaya Pengendalian Banjir', J. Pemberdaya. Masy. Madani JPMM, 1, 296-308. 